\title{
Efektifitas Pemberian Jus Buah Bit (Beta Vulgaris. L) Sebagai Minuman Fungsional Penurun Tekanan Darah pada Lansia
}

\author{
Effectiveness of Beet Juice (Beta Vulgaris. L) as a Functional Drink of Blood \\ Pressure in Elderly
}

\author{
Devillya Puspita Dewi ${ }^{*}$, Kuntari Astriana ${ }^{2}$ \\ 1,2 Prodi S1 Ilmu Gizi Fakultas Ilmu Kesehatan Universitas Respati Yogyakarta \\ Jl. Tajem km 1,5 Maguwoharjo Depok Sleman Yogyakarta \\ *email : deandra_bram@yahoo.com
}

DOI;

10.30595/jrst.v3i1. 3596

Histori Artikel:

Diajukan:

$13 / 11 / 2018$

Direvisi:

$14 / 03 / 2019$

Diterima:

28/03/2019

\section{ABSTRAK}

Buah bit merupakan salah satu bahan makanan lokal yang kaya kandungan gizi dan senyawa aktif. Kandungan yang tinggi dalam buah bit diantaranya adalah kalium. Senyawa aktif dalam buah bit diantaranya antioksidan (betalain). Mineral kalium dan antioksidan ini merupakan zat yang dapat menurunkan hipertensi. Tujuan penelitian ini untuk mengetahui efektifitas pemberian jus buah bit (Beta vulgaris L) terhadap kejadian hipertensi pada lansia. Jenis penelitian yang digunakan adalah kuasi eksperimen dengan rancangan Pre test post test control trial dengan intervensi pemberian jus buah bit beberapa 3 kali frekuensi kepada lansia. Sampel yang akan diambil berjumlah 22 lansia hipertensi. Data yang diambil tekanan darah, status gizi. Analisa data menggunakan paired t test. Dari hasil penelitian dapat diperoleh data bahwa sebagian besar responden berumur $>60$ tahun (elderly) $54,5 \%$, jenis kelamin perempuan $90,1 \%$ dan mempunyai status gizi normal 59,1\%. Tekanan darah sistolik sebelum pemberian jus buah bit 140-159 mmHg Borderline Isolated 40,9\% dan sesudah pemberian jus buah bit $45,5 \%$. Selisih tekanan darah sistolik sebelum dan setelah pemberian jus buah bit 15,86 dan selisih tekanan darah diastolik sebelum dan setelah pemberian jus buah bit sebanyak 5,00. Tekanan darah diastolik sebelum pemberian jus buah bit 90-104 $\mathrm{mmHg}$ (sedang) 45,5\% dan setelah pemberian jus buah bit, $85 \mathrm{mmHg}$ (normal) 36,4\%. Ada pengaruh pemberian jus buah bit terhadap kejadian hipertensi pada lansia.

Kata Kunci : Jus, buah bit, hipertensi, lansia

\footnotetext{
ABSTRAK

Beetroot is one of the local food ingredients that are rich in nutrients and active compounds. The high content of the beet fruit is potassium. The active compounds in the beet fruit include antioxidants (betalain). This mineral potassium and antioxidant is a substance that can reduce hypertension. The objective of this research is to find out the effectiveness of beet juice (Beta vulgaris $L$ ) to the incidence of hypertension in the elderly. The type of research used was quasi-experimental design with pre-test post-test control trial with the intervention of giving beetroot juice several times three times the frequency to the elderly. Samples to be taken amounted to 22 elderly hypertension. Data taken by blood pressure, nutritional status. Analysis of data using the paired t-test. From the results of the study can be obtained data that the majority of respondents aged> 60 years (elderly) $54.5 \%$, female gender 90.1\% and have normal nutritional status 59.1\%. Systolic blood pressure before giving of beetroot juice 140-159 mmHg Borderline Isolated was 40.9\% and after giving of beetroot juice $45.5 \%$. The difference in systolic blood pressure before and after the giving of 15.86 beet juice and diastolic blood pressure difference before and after giving of beetroot juice as much as 5.00. Diastolic blood pressure
} 
before giving of beetroot juice 90-104 $\mathrm{mmHg}$ (moderate) $45.5 \%$ and after giving of beetroot juice, 85 $\mathrm{mmHg}$ (normal) $36.4 \%$. There is an effect of giving beetroot juice to the incidence of hypertension in the elderly.

Keywords: juice, beet fruit, hypertension, elderly

\section{PENDAHULUAN}

Hipertensi merupakan salah satu masalah kesehatan masyarakat yang perlu mendapat perhatian karena penyakit ini akan berpengaruh terhadap kesehatan baik jangka pendek maupun jangka panjang (Vitahealth, 2005). Prevalensi hipertensi di Asia sekitar 8$18 \%$ di Indonesia prevalensi hipertensi sekitar 9,5\%. Prevalensi hipertensi di Daerah Istimewa Yogyakarta sekitar 13\% artinya prosentase diatas prevalensi nasional (Kemenkes RI, 2013). Hipertensi dipengaruhi oleh gaya hidup yang tidak sehat yang terjadi di masyarakat seperti stress, obesitas/kegemukan, merokok, kurang aktifitas, makanan tinggi lemak, tinggi natrium dan asupan kalium yang rendah. Hipertensi adalah tekanan darah sistolik $\geq 140 \mathrm{mmHg}$ atau tekanan darah diastolik $\geq 90 \%$.

Angka harapan hidup manusia Indonesia semakin meningkat sejalan dengan meningkatnya taraf hidup dan pelayanan kesehatan. Kondisi ini membuat populasi usia lanjut di Indonesia semakin tinggi (Kemenkes RI, 2013). Jumlah penduduk Indonesia yang berusia 60 tahun ke atas dari tahun ke tahun mengalami peningkatan. Berbagai gangguan kesehatan yang disertai kecatatan tubuh pada golongan usia lanjut sebagai akibat gaya hidup dan pola makan yang salah, jika tidak diantisipasi dengan baik akan merupakanmasalah yang serius bagi bangsa Indonesia. Dengan bertambahnya jumlah usia lanjut, pola penyakit juga bergeser ke arah penyakit degeneratif yang berkaitan erat dengan konsumsi bahan makanan (Hanifan, 2016).

Usia lanjut mempunyai kecenderungan gaya hidup yang kurang sehat seperti pola makan tidak teratur, kurang aktifitas, kurangnya asupan serat dan berbagai masalah yang dapat memicu stress. Adanya kondisi demikian yang usia lanjut akan lebih rentan penyakit dan mempercepat proses penuaan. Banyak perubahan yang dialami usia lanjut dan perlu diwaspadai seperti hipertensi, pengerasan pembuluh darah, serangan jantung, gangguan pencernaan .

Buah bit merupakan salah satu jenis bahan pangan yang bermanfaat dan kaya dengan zat gizi. Salah satu manfaat buah bit adalah sebagai pewarna alami dalam pembuatan pangan olahan. Pigmen yang terdapat pada buah bit merah adalah betalain. Betalain merupakan golongan antioksidan (Wirakusumah, 2007). Kandungan vitamin dan mineral yang ada dalam bit merah seperti vitamin B dan kalsium, kalium, fosfor, besi merupakan nilai lebih dari penggunaan bit merah. Kalium merupakan ion intraseluler dan dihubungkan dengan mekanisme pertukaran natrium. Peningkatan asupan kalium dalam diet telah dihubungkan dengan penurunan tekanan darah karena kalium memacu kehilangan natrium lewat urin (Kerry and Ledward, 2001).

Buah bit mengandung beberapa senyawa aktif seperti karotenoid, glisin betain, saponin, betasianin, betanin, polyphenol dan falvonoid (Singh dan Hathan, 2013). Buah bit kaya karbohidrat yang mudah menjadi energi serta za besi yang membantu darah mengangk ut oksigen ke otak. Bit berwarna merah, warna ini disebabkan oleh gabungan pigmen ungu betasianin dan pigmen kuning betasantin.

Buah bit kaya dengan kandungan gizi seperti asam folat (menumbuhkan dan mengganti sel-sel yang rusak), kalium (memperlancar keseimbangan cairan di dalam tubuh), vitamin C (menumbuhkan jaringan dan menormalkan saluran darah), magnesium (menjaga fungsi otot dan syaraf), zat besi (metabolisme energi dan sistem kekebalan tubuh), tembaga (membentuk sel darah merah), fosfor (memperkuat tulang), caumarin (mencegah tumor) dan betasianin. Buah bit mengandung antosianin sebesar $51,50 \mathrm{mg} / 100$ gram sampai dengan $174,70 \mathrm{mg} / 100$ gram. Pigmen yang terdapat dalam umbi bit juga dapat memberikan warna ungu kemerahan yang akan membuat warna es krim menjadi lebih menarik tanpa penambahan warna sintetis (Hanifan, 2016).

Tujuan penelitian ini adalah untuk mengetahui pengaruh pemberian jus buah bit (Beta vulgaris $L$ ) terhadap kejadian hipertensi pada lansia

\section{METODE PENELITIAN}

Jenis penelitian ini adalah quasi eksperimen dengan rancangan one group Pretest Posttest tanpa kelompok kontrol. Penelitian ini dilaksanakan pada bulan JuliSeptember 2018 di Desa Pleret. Sampel dalam 
penelitian ini adalah lansia yang menderita hipertensi dan diberikan intervensi jus buah bit selama sehari dua kali dalam waktu satu minggu. desain ini observasi dilakukan sebanyak dua kali yaitu sebelum eksperimen dan sesudah eksperimen. Pemberian jus buah bit dilakukan setiap hari selama satu minggu setelah pemberian dilakukan pengukuran tekanan darah. Formulasi pembuatan jus buah bit adalah buah bit dan air dengan perbandingan 30\% : 70\%. Analisa data menggunakan pairet t test.

\section{HASIL DAN PEMBAHASAN}

\subsection{Karakteristik Responden}

Dari hasil penelitian dapat diperoleh data tentang karakteristik responden berupa umur, jenis kelamin lansia. Data karakteristik responden dapat dilihat pada tabel 4 dibawah.
Tabel 1. Karakteristik Responden

\begin{tabular}{ccc}
\hline $\begin{array}{c}\text { Karakteristik } \\
\text { Responden }\end{array}$ & $\begin{array}{c}\text { Frekuensi } \\
\text { (f) }\end{array}$ & $\begin{array}{c}\text { Prosentase } \\
\text { (\%) }\end{array}$ \\
\hline Umur (tahun) & & \\
55-60 (middle age) & 10 & 45,5 \\
>60 (elderly) & 12 & 54,5 \\
Jenis Kelamin & & \\
Perempuan & 20 & 90,1 \\
Laki-laki & 2 & 0,9 \\
Status Gizi & & \\
Kurus & 3 & 14,6 \\
Normal & 13 & 59,1 \\
Gemuk & 8 & 36,3 \\
Total & 22 & 100 \\
\hline
\end{tabular}

Berdasarkan Tabel 1 di atas karakteristik umur sebagian besar berusia lebih dari lebih dari 60 tahun sebanyak 54,5\%, sedangkan untuk jenis kelamin sebagian besar perempuan sebanyak 90,1\%.

\subsection{Tekanan Darah Responden}

Berdasarkan data tekanan darah responden sistolik dan diastolik yang dilihat sebelum dan setelah pemberian jus buah bit. Tekanan darah sistolik responden dikategorikan menjadi tekanan darah 140 mmHg dalam kategori normal, 140-159 mmHg dalam kategori Borderline Isolated Systolic Hypertension dan lebih dari 160 mmHg kategori Isolated Systolic Hypertension.

Tabel 2. Tekanan Darah Sistolik Sesudah Dan Sebelum Pemberian Jus Buah Bit

\begin{tabular}{lcccc}
\hline \multirow{2}{*}{ Tekanan Darah Sistolik } & \multicolumn{2}{c}{ Sebelum } & \multicolumn{2}{c}{ Sesudah } \\
& $\mathrm{f}$ & $\%$ & $\mathrm{f}$ & $\%$ \\
\hline $140 \mathrm{mmHg}$ (Normal) & 5 & 22,7 & 7 & 31,8 \\
$140-159 \mathrm{mmHg}$ (Borderline Isolated) & 9 & 40,9 & 10 & 45,5 \\
$>160 \mathrm{mmHg}$ (Isolated Systolic Hypertension) & 8 & 36,4 & 5 & 22,7 \\
$\quad$ Total & 22 & 100 & 22 & 100 \\
\hline
\end{tabular}

Dari Tabel 2 di atas dapat diketahui bahwa sebelum diberikan jus buah bit sebagian besar responden mempunyai tekanan darah sistolik Borderline Isolated sebanyak 40,9\%. Sedangkan sesudah diberikan jus buah bit sebagian besar responden juga mempunyai tekanan darah sistolik Borderline Isolated sebanyak 45,5\%. Ada penurunan jumlah responden dengan tekanan darah sistolik pada Isolated Systolic Hypertension dari 36,4\% menjadi $22,7 \%$.

Tekanan darah diastolik responden sebelum dan sesudah diberikan jus buah bit dapat dilihat pada Tabel 3 dibawah.

Tabel 3. Tekanan Darah Sistolik sesudah dan sebelum pemberian jus buah bit

\begin{tabular}{lcccc}
\hline \multicolumn{1}{c}{ Tekanan Diastolik } & \multicolumn{2}{c}{ Sebelum } & \multicolumn{2}{c}{ Sesudah } \\
& $\mathrm{F}$ & $\%$ & $\mathrm{f}$ & $\%$ \\
\hline$<85 \mathrm{mmHg}$ (Normal) & 7 & 31,8 & 8 & 36,4 \\
85-89 mmHg (Ringan) & 1 & 4,5 & 6 & 27,3 \\
$90-104 \mathrm{mmHg}$ (Sedang) & 10 & 45,5 & 6 & 27,3 \\
$105-114 \mathrm{mmHg}$ (Berat) & 3 & 13,6 & 2 & 9,1 \\
$>115 \mathrm{mmHg}$ (Berbahaya) & 1 & 4,5 & 0 & 0,0 \\
\multicolumn{1}{c}{ Total } & 22 & 100 & 22 & 100 \\
\hline
\end{tabular}


Berdasarkan Tabel 3 di atas dapat diketahui bahwa tekanan darah diastolik sebelum pemberian jus buah bit mempunyai kadar diastolik sedang (90-104 mmHg) sebagian besar 45,5\%. Sedangkan untuk kadar diastolik sesudah pemberian jus bit mempunyai kadar diastolik normal (kurang dari $85 \mathrm{mmHg}$ ) sebagian besar 36,4\%.

\subsection{Pengaruh Pemberian Jus Bit terhadap Tekanan Darah Lansia}

Data tekanan darah lansia berdasarkan tekanan darah sistolik dan diastolik dapat dilihat padat Tabel 4 di bawah.

Tabel 4. Perbedaan Rerata Tekanan Darah Pre dan Post Pemberian Jus Bit

\begin{tabular}{ccccc}
\hline Tekanan & \multicolumn{2}{c}{ Perlakuan } & \multirow{2}{*}{ Selisih } & p \\
Darah & Pre $(\mathrm{mmHg})$ & Post $(\mathrm{mmHg})$ & & 15,86 \\
\hline Sistolik & $170,86 \pm 25,67$ & $155,00 \pm 21,46$ & 0,000 \\
Diastolik & $97,54 \pm 12,88$ & $92,54 \pm 12,14$ & 5,00 & 0,014 \\
\hline
\end{tabular}

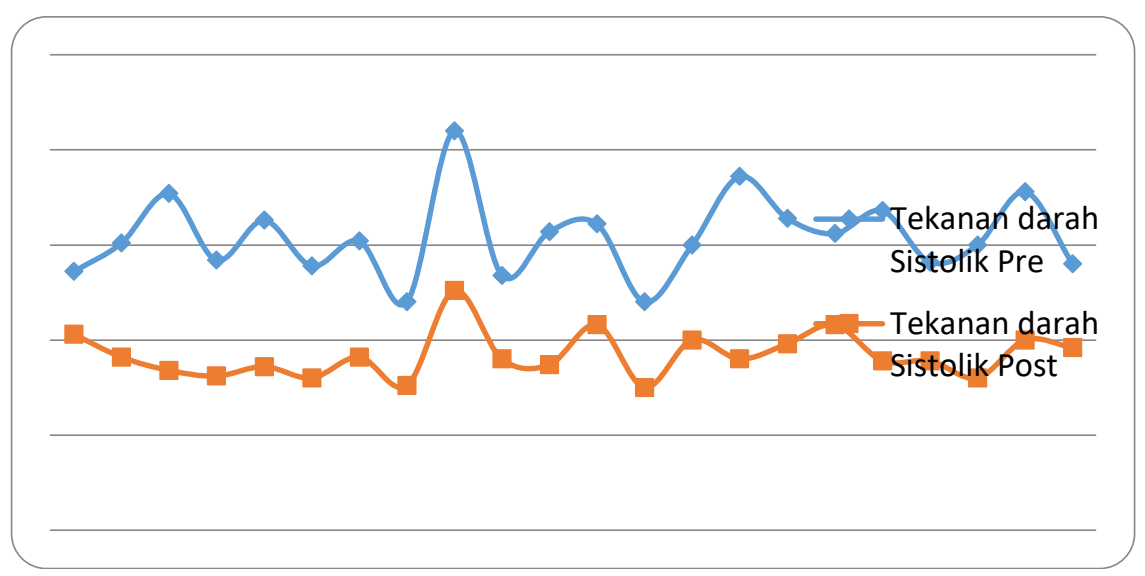

Gambar 1. Tekanan Darah Sistolik Sebelum dan Setelah Pemberian Jus Buah Bit

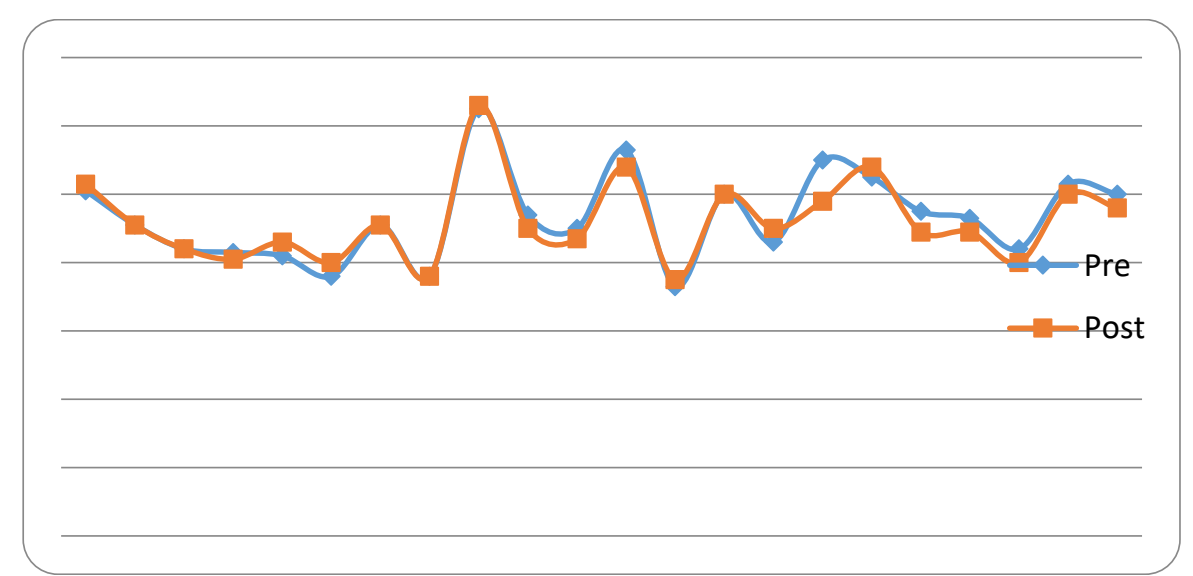

Gambar 2. Tekanan Darah Sistolik Sebelum dan Setelah Pemberian Jus Buah Bit

Dari Tabel 3 di atas menunjukkan bahwa setelah diberikan intervensi berupa pemberian jus bit sebanyak 6 kali selama 1 minggu ditemukan penurunan rerata tekanan darat sistolik sebanyak 15,86 $\mathrm{mmHg}$ dan signifikan secara statistik $(p<0,000)$ artinya ada pengaruh pemberian jus buah bit terhadap kadar tekanan darah sistolik pada lansia. Sedangkan apabila dilihat berdasarkan rerata skor setelah perlakuan (post), menunjukkan adanya penurunan skor diastolik sebesar 5 mmHg dan signifikan secara statistik $(\mathrm{p}<0,000)$ ada pengaruh pemberian jus buah bit terhadap kadar tekanan darah diastolik pada lansia.

Tekanan darah tinggi atau sering disebut dengan hopertensi merupakan suatu keadaan dimana tekanan darah sistolik seseorang lebih dari sama dengan $140 \mathrm{mmHg}$ dan atau tekanan darah diastolik lebih dari 90 
mmHg. Dari hasil penelitian dapat dilihat bahwa sebagian besar responden berumur lebih dari 60 tahun (elderly) sebanyak 12 orang $(54,5 \%)$. Prevalensi kejadian hipertensi meningkat dengan bertambahnya usia. Seseorang rentan mengalami kejadian hipertensi diawali pada usia lebih dari 20 tahun (Black dan Hawks, 2006).

Penambahan umur akan menyebabkan terjadinya perubahan pada semua organ terutama sistem kardiovaskuler. Sehingga dapat diketahui bahwa semakin meningkatnya umur maka makin meningkatkan resiko terjadinya hipertensi yang disebabkan karena proses degeneratif (Syukraini, 2009). Hal ini disebabkankarena tekanan arteri yang meningkat sesuai dengan bertambahnya usia, terjadi regurgitasi aorta yang sering terjadi pada usia tua. TDS (tekanan darah sistolik) meningkat sesuai dengan peningkatan usia, tetapi untuk TDD (tekanan darah diastolik) meningkat seiring dengan TDS sampai usia 55 tahun.

Untuk jenis kelamin responden sebagian berjenis kelamin perempuan sebanyak 20 orang $(90,1 \%)$. Wanita lebih banyak yang menderita hipertensi dibandingkan dengan laki-laki hail ini disebabkan karena terdapat hormon estrogen. Hormon estrogen pada wanita akan semakin menurun setelah masa menopause (Amaliah dan Sudikno, 2014). Hal ini sesuai dengan penelitian Tesyafe et al (2007) bahwa ada hubungan antara jenis kelamin dengan kejadian hipertensi, prevalensi hipertensi pada wanita lebih besar dibandingkan laki-laki disebabkan karena adanya pengaruh genetik dan umur.

Status gizi merupakan keadaan keseimbangan antara asupan dan kebutuhan gizi seseorang. Berdasarkan karakteristik responden sebagian besar mempunyai status gizi normal sebanyak 59,1\%. Seseorang dengan status gizi normal bisa juga mengalami hipertensi yang disebabkan karena sistem simpatis dan sistem renin angiotensin (Asrinawaty dan Norfai, 2014).

Hasil penelitian dapat dilihat bahwa sebelum diberikan jus buah bit sebagian besar responden mempunyai tekanan darah sistolik Borderline Isolated sebanyak 40,9\%. Salah satu faktor resiko hipertensi adalah usia, semakin tua seseorang semakin berpotensi terjadi kejadian hipertensi. Sedangkan sesudah diberikan jus buah bit sebagian besar responden juga mempunyai tekanan darah sistolik Borderline Isolated sebanyak 45,5\%. Ada penurunan jumlah responden dengan tekanan darah sistolik pada Isolated Systolic Hypertension dari $36,4 \%$ menjadi $22,7 \%$. Tekanan darah sistolik sebelum pemberian jus buah bit mempuntai rerata $170,86 \pm 25,67$ dan rerata setelah pemberian jus buah bit $155,00 \pm 21,46$ sehingga dapat diketahui selisih rerata sebesar 15,86. Hasil analisa paired test dapat diketahui bahwa ada pengaruh pemberian jus buah bit terhadap tekanan darah sistolik $(\mathrm{p}<0,05)$.

Tekanan darah diastolik sebelum pemberian jus buah bit mempunyai kadar diastolik sedang (90-104 $\mathrm{mmHg}$ ) mempunyai prosentase terbesar sebanyak 45,5\%. Sedangkan untuk kadar diastolik sesudah pemberian jus bit mempunyai kadar diastolik normal (kurang dari $85 \mathrm{mmHg}$ ) dengan prosentase sebanyak 36,4\%. Lansia cenderung mengalami peningkatan tekanan darah seiring dengan bertambahnaya usia. Peningkatan tekanan darah pada lansia umumnya terjadi akibat penurunan fungsi organ pada istem kardiovaskuler. Katup jantung menebal dan menjadi kaku, serta terjadi penurunan elastisitas dari aorta dan arteri-arteri besar lainnya. Selain itu terjadi peningkatan resistensi pembuluh darah perifer ketika ventrikel kiri memompa, sehingga tekanan sistolik dan afterload meningkat (Prakoso dkk, 2014).

Hasil penelitian ini menjelaskan bahwa jus buah bit mempunyai pengaruh yang signifikan terhadap penurunan tekanan darah atau hipertensi. Hal ini disebabkan karena kandungan zat gizi yang terdapat pada buah bit sangat kompleks diantaranya kalium, antioksidan, kalsium dan besi yang tinggi. Kandungan zat gizi inilah yang mneyebabkan terjadinya penurunan tekanan darah pada lansia. Penurunan hipertensi dapat dilakukan dengan cara mengkonsumsi buah-buahan. Intervensi yang diberikan pada penelitian ini adalah pemberian jus buah bit.

Zat gizi yang paling tinggi pada jus buah bit yang diintervensi adalah kalium. Mengkonsumsi kalium dalam jumlah yang tinggi akan meningkatkan konsentrasi di dalam cairan intraseluler, sehingga cenderung menarik cairan dari bagian ekstraseluler dan menurunkan tekanan darah. Kalium yang terkandung dalam 100 gram buah bit sebesar $10-15 \%$ dan merupakan zat gizi yang paling banyak terkandung dalam buah bit 


\section{KESIMPULAN}

Karakterisitik responden sebagian besar berusia $>60$ tahun (elderly) 54,5\%, jenis kelamin perempuan $90,1 \%$ dan berstatus gizi normal $59,1 \%$. Ada pengaruh pemberian jus buah bit terhadap tekanan darah sistolik dan diastolik pada lansia $(\mathrm{p}<0,05)$. Saran bagi penderita hipertensi adalah melakukan penanganan hipertensi dengan menggunakan jus buah bit sehingga hipertensi dapat segera ditanggulangi.

\section{DAFTAR PUSTAKA}

Vitahealth. (2005). Hipertensi. Jakarta: Gramedia.

Kemenkes RI. (2013). Riset Kesehatan Dasar. Dinas Kesehatan RI

Wirakusumah, E. (2007). Cantik Awet Muda Dengan Buah Sayur dan Herbal. Jakarta: Penebar Swadaya.

Kerry J and D Ledward. (2001). Meat Processing. New York : CRC

Singh, B and Hathan, S.B. (2013). Optimization Of Osmotic Dehydration Process of Beetroot (Beta Vulgaris) in Sugar Solution Using RSM. International Journal of Food Agriculture and Veterinary Sciences. Vol. 3 (3) September-Desember.

Hanifan, F., Ruhana, A., dan Hidayati, DYN. (2016). Pengaruh Substitusi Sari Umbi
Bit (Beta vulgaris L) terhadap Kadar Kalium, Pigmen Betalain dan Mutu Organik Permen Jeli. Majalah Kesehatan FKUB. Volume 3, Nomer 4, Maret 2016.

Black JM, Hawk JH. (2005). Medical Surgical Nursing : Clinical Management For Positive Outcomes. 7th edition. St. Louis: Elsevier Saunders

Tesfaye F, Nawi NG, Minh HV, Byass P, Berhane Y, Bonita R, S Wall. (2007). Association Between Body Mass Index and Blood Presure Across Three Population in Africa and Asia. Journal of Human Hypertension, 21: 28-37

Amaliah, F dan Sudikno. (2014). Faktor Risiko Hipertensi Pada Orang Umur 45-74 Tahun di Pulau Sulawesi. Gizi Indon 2014, 37(2): 145-151.

Asrinawaty dan Norfai. (2014). Hubungan Status Gizi dengan Kejadian Hipertensi Lansia di Posyandu Lansia Kakaktua Wilayah Kerja Puskesmas Pelambuan. An Nadaa. Vol 1 No. 1, Juni 2014, Hal 32-36.

Prakoso, A. Agusman, FMM. Sonhaji. (2014). Pengaruh Pemberian Jus Mentimun Terhdap Tekanan Darah Pada Lansia Dengan Hipertensi DI Posyandu di Kabupaten Demak. Prosiding Konferensi II PPNI Jawa Tengah 2014 